
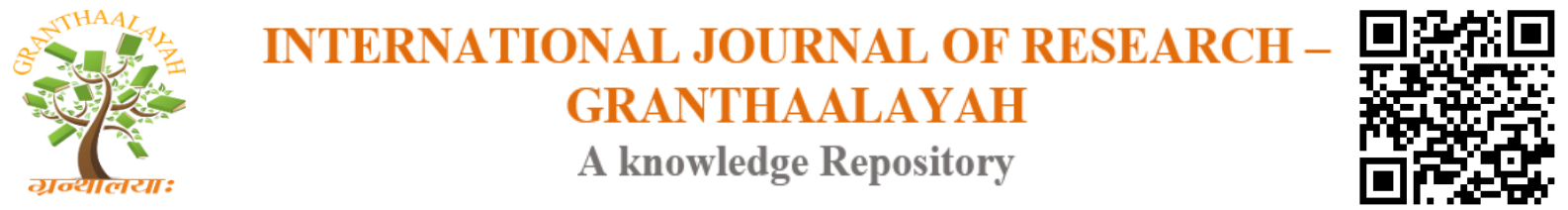

Social

\title{
THE EFFECTIVENESS OF SCAFFOLDING METHOD ON STUDENTS' SPEAKING ACHIEVEMENT
}

\author{
Lamhot Naibaho *1 \\ ${ }^{1}$ Universitas Kristen Indonesia
}

\begin{abstract}
This study is about the effectiveness of scaffolding method on students' speaking achievement, and it is aimed to know effectiveness of scaffording method on students' speaking skill. It was done at Universitas Kristen Indonesia on students' speaking class of batch 2017. The method of the study is classroom action research, which was carried out within 2 cycles. The instrument of the study used was test sheet and observation sheet and the data taken using the instruments were analyzed by using descriptive statistics. The result of the study shows that scaffolding method is effective on improving students' speaking achievement. ding can improve students' speaking skills. It is concluded that scaffolding method is a good method to be implemented at speaking class, and the lecturers are suggested to use scaffolding method when teaching speaking in the classroom.
\end{abstract}

Keywords: Effectiveness; Scaffolding Method; Speaking Achievement.

Cite This Article: Lamhot Naibaho. (2019). "THE EFFECTIVENESS OF SCAFFOLDING METHOD ON STUDENTS' SPEAKING ACHIEVEMENT.” International Journal of Research - Granthaalayah, 7(5), 193-201. https://doi.org/10.29121/granthaalayah.v7.i5.2019.839.

\section{Introduction}

Speaking is basically someone's ability to issuing ideas or thoughts to others through oral language. Among of the four skills (listening, speaking, reading, and writing) in learning English, speaking seems intuitively the most important. It also becomes crucial for part of second and foreign language learning and teaching, because it consists of producing and conveying ideas and messages systematically to the interlocutor. Learning English is very complex because English consists of four skills, including speaking skills, then reading (writing), writing (writing), and listening (listening) and skills these are interconnected with each other. In every language skill has a very close relationship with one another. ${ }^{1,2}$ In acquire language skills usually through a relationship that is sequential and orderly, first by learning to listen or hear, then speak, after that learn to read and write.

The ability to speak is one aspect of language skills, speaking is a skill convey messages through spoken language. A lot of students attend an English course although they have learned English in 
the classroom, in order to be able to speak English. The ability of students on using English to communicate with others at Universitas Kristen Indonesia are still considered low. It can be seen through the achievement in the classroom, where almost $85 \%$ of the students find it difficult to communicate the ideas in their mind whether among the students or the students and the lecturers. In speaking, the students find it difficult to convey information/messages spoken by the speaker. Students tend to be less fluent in talking or telling stories at before his friends. ${ }^{3}$ Sometimes there are students who only able to say a few sentences or even to be silent when they are standing in front of the class.

This is due to the lack of material or concepts that will be spoken up by the students. According to the results of observation did by the speaking class lecturer when teaching the students, he found out a number of problems faced by the students, as follows: firsts, most of the students are passive when speaking, second, the students use more Indonesian rather than English, third, the use of grammatical structures which is not right, and last, they are still afraid to speak using English even with their classmate.

The four problems are the causes of students' lack of skill while speaking, and the low learning outcomes of students' speaking skills, as follows: the average score is 68 , while grades the minimum completeness in speaking skills is 75 . Only 6 students from 22 students who reach the 75-80 value range. The rest, as many as 16 students with range $40-74$. Such information shows that the ability of speaking of the students are not very encouraging.

Based on the conditions that occur in English speaking skills above, improvement through action is necessary done then students' speaking achievement can be improved. After reading some theories about the methods used to improve the students' speaking achievement, the researcher is interested to a method, it is scaffolding method. One effort that can be done to improve students' speaking skills through the application the teaching approach is in accordance with the assumption that speaking competence students will be better. In an effort to improve students' speaking achievement, researchers use a scaffolding method, where this strategy is in learning to speak English also involves three other skills. Scaffolding is a learning activity that is associated with the real world to achieve goals through the use of simple language, images shown by the teacher, cooperative learning, and prepare the previous learning device by the teacher. ${ }^{4,5,6}$

In the scaffolding learning method there are several ways you can teachers do include: (1) using simple language, (2) completing the sentence or paragraph by selecting the available answers, (3) using images to convey information. ${ }^{7,8}$ Implementation of scaffolding method learning in addition to helping improve speaking skills students are also able to increase students' creativity, because they are inside scaffolding learning has a purpose and understanding that has something to do with development of students' self-concepts.

The purpose and understanding of learning Scaffolding includes: (1) stimulating student development, (2) stimulating student creativity, (3) improve and improve the teaching process, (4) help develop students' self-concept, (5) give attention and guidance to students, (6) stimulate student reflection, and (7) help and rectify learning objectives. ${ }^{9,10}$ Besides that, the scaffolding learning method has advantages that are not possessed by conventional learning methods. This advantage is reflected in the high creativity of students, growing students' sense of responsibility 
in carrying out the tasks given, improve the ability to think systematically and organized so that produce the best work. ${ }^{11,12}$

Through this scaffolding method students are expected to be diverse in character get the learning process to speak English according to their needs so that they are able to achieve that competence expected. Students of speaking class of batch 2017 Universitas Kristen Indonesia also mostly have an unencourage ability to speak English, while in reality speaking ability is very crucial remembering they must be in direct contact with expressions in English which is more formal and scientific, such as: speech and presentation of the results of group discussions in front of the class. Based on the discussion above, in this study, researchers did a research related to speaking skills of students of students of speaking class of batch 2017 Universitas Kristen Indonesia in expressing true and clear phrases with apply scaffolding method. This research is carried out by applying action research steps with the title: Method implementation of scaffolding in improving speaking skills. This research was conducted on students of students of speaking class of batch 2017 Universitas Kristen Indonesia.

This study generally aims to address student problems in an effort to improve speaking skills and explore student skills in expressing expressions true and clear using the scaffolding method so English speaking skills are better. The benefits of this research is to train students to use scaffolding method for improve their speaking skills, increase the type of vocabulary research in the field of English language education is a reference for determination scaffolding method as one of the learning approaches that are appropriate student characteristics, provide recommendations to related parties for applying scaffolding method in accordance with the conditions of each student, providing alternative learning techniques for educators to improve English language skills of students, especially in speaking English.

\section{Method}

This research is a classroom action research ${ }^{13}$ which is aimed to improving students speaking achievement through scaffolding method. The classroom action research which consists of four stages in each cycle, namely: the planning, the implementation, the observation, and the reflection. ${ }^{14,15,16}$, At the planning stage, includes the preparation of the implementation of lesson plan, tools and media; conversation text, and instrument for collecting the data (speaking tests, observation checklists). At the stage implementing, the scaffolding method was applied to teach speaking to the subject research. ${ }^{17}$ This implementation of scaffolding method was inplemented through the steps in the lesson plan. Then after that, while implementing the scaffolding method, the teacher and the collaborator made observation while teaching. The collaborator observed the situation in the classroom during the learning process. Collaborators fill the observation checklist when observing the class to get data of the research from the implementation of the scaffolding method in the learning process.

The last stage is, reflection stage, researcher and collaborators discuss the results of observations on the implementation of scaffolding method during the learning process. The observations was in the form of student activities inside class, the state of the class during the teaching and learning process, the use of learning tools and media, and also on teaching abilities in delivering learning 
material. With reflection, researchers and collaborators find advantages and disadvantages and evaluate learning and learning process.

The subject of this research was students of students' speaking class of batch 2017, the number of the students were 22 persons. The technique of data collection was carried out with the following steps: (1) Making learning observations to find problems learning. (2) Designing and determining learning techniques and scenarios learning is done, as well as conducting discussions with subject teachers English to obtain pre-observation data validation, device learning and research instruments. (3) Testing instruments learning that has been compiled and records the learning process occur in class in the form of observation sheets for learning activities and fields note. (4) Giving speaking test to determine the success of the use learning approach in improving students' speaking skills.

Data analysis in this study is descriptive statistical analysis conducted to determine the success of the implementation of scaffolding method used to increase students' skills in speaking. The statistics descriptive analysis are in the form of averages or percentages of the results of speaking tests of the students, and affective descriptions of students to determine the level of behavior change students towards the learning process.

\section{Results and Discussion}

The results of data analysis obtained through this study are seen from several affective aspects in the first, second, and second cycles, namely: discipline and student activity during the learning process, student learning motivation, and response students on learning activities use scaffolding method. The results obtained from the observation checklist are as follows: First. In the first cycle, seen from the activity of students during the learning process, when the learning process takes place $67 \%$ of students who listens and gives full attention to the teacher is presenting some important information, including when deliver learning objectives, material learned, and videos and images related to learning material.

In applying the scaffolding strategy, especially in the presentation of results from group discussions in the form of a conversation, no more than $51 \%$ of students spoke English well. Some of them carry and read text when they had presentations in front of class and the ability to speak English is not good still. Then, during discussion in groups to make a conversation, about $49 \%$ of students could not convey their ideas or ideas well.

Meanwhile, in the second cycle, during the learning process, almost all students listen and pay close attention to the explanations and important information from the teacher regarding the learning objectives, the material to be studied, videos and images displayed. When students were asked to having a conversation from the results of group discussions, mostly students were able to present in front of the class without carrying or reading text. The ability to speak English then become better or improve comparing to the first cycle. In discussion activities, $75 \%$ of students were able to pair up share ideas with their partners about conversations which was assigned to be presented by the students. 
In the second cycle also, the second and fourth meetings of all students were on time to come to the classroom, so that when the learning process takes place students were more serious listen and pay attention to important information from the teacher and watch the video related to the topic to be studied. When playing a role almost all students are able to speak English in front of the class without carrying and reading text, so they are more confident in sharing ideas or ideas with his friend. English language skills of students become much better from previous cycles.

Second, in the first cycle, it was seen from students' learning motivation, less than $25 \%$ students who are enthusiastic about participating in learning activities during the process learning. Some students don't listen well to the video displayed and when playing a role most students are not yet willing to appearing in front of the class. In the second cycle, more than $75 \%$ of students felt motivated to follow learning activities. Students listen carefully to the video displayed, some students asked questions with the teacher about the material and videos that is. Then in the second cycle, the third and fourth meetings of all students more enthusiastic about learning activities. Almost all students share ideas and ideas with the group about the conversation that will displayed in front of the class. Students are also willing to play roles in front of the class with their partner, without being appointed by the teacher first.

Second, in the first cycle, it was seen from the positive response given by students, no students have tried to express their opinions. Only $37 \%$ students who feel excited about giving answers to questions submitted by the teacher during the learning process. Then, during the process learning takes place there are 5 students who ask questions about the difficulties, that make students understand the material taught and video displayed. Discussion activities in the first cycle, almost all students are willing give ideas and ideas but there are some students who are difficult respect and accept their friends' ideas regarding the material being studied and conversations made in groups.

However, in the second cycle students gave a very positive response with more than $75 \%$ of students who have tried their opinions. When ask some questions about the material explained the teacher, in the second cycle more changed than at first cycle. Unlike the first and second cycles, in the second cycle almost all students ask questions related to the material and videos displayed, although they tend to be more personal when the teacher monitors students discuss with group friends. All students are able to elaborate on ideas and the ideas of his friends so that they produce a good conversation.

In the second cycle, all four students had responded which is very good. Students are able to respond well to questions given by the teacher. The whole group is able to produce a good conversation related to the material that has been learned. In each cycle, students participate in learning activities well. All students are willing do the assignments and exercises given by the teacher well.

The next data obtained is sourced from the field that provides important information to support and complete the results obtained from observation checklist. The following is an explanation of the observations obtained use field notes. First, in the first cycle seen from student activities. Almost partially student groups cannot complete conversations conducted in any way group according to the time specified, then at that time presenting the results of group discussions, only 
5 groups from 12 groups different that responds to the appearance of his friend show conversation results. Many students are not fluent speak English and use grammar is not right when present the results of the conversation that has been done.

Then in the second cycle, almost all groups can complete timely conversation. Then at the presentation, each group respond to his friend's appearance. Almost all students too able to speak English more smoothly and use grammar more precise. Second, in the first cycle, student learning motivation was seen the confused make conversation using their own words. Most of them still use the same words as them shown from videos and examples of conversations from the teacher. In this cycle, students also tend to be afraid of making mistakes, especially in the use of grammar that will be used in their conversation. Neither student motivated to practice with friends a group of expressions as read by the teacher. In the first cycle, most students were not too motivated review and conclude learning material. Unlike the second cycle and second, where students look more excited through group discussions make a conversation using your own words according to the theme study at that time.

In the second cycle, more students are willing to do repetition of several expressions, so that it looks better and better pronunciation students' grammar in saying a few expressions. Third, in the first cycle seen from the positive response given by students. Some students do not respond to their friends' appearance at the moment display conversation results of the discussion. At the language proficiency test English, the first cycle of most students felt less confident and nervous because they are present in front of the class individually. In the second cycle and second, enthusiastic students present the results of the conversation through discussion groups, other students listen carefully, and most ask each other questions and give input. Then, almost all students are serious and more trusting yourself to appear speaking English in front of the class individual.

Based on the results of the two groups of affective aspects that have been described above, almost all shows an increase or change in behavior which is better than before. The results of this speaking test was thoroughly explained per cycle, starting from the first cycle to the second cycle. In the first cycle, based on observations as long as students display a conversation in front of the class based on the results of the discussion, students' speaking skills experience an increase in score results before scaffolding method is applied, though the increase is still a relatively small percentage. In the first cycle, results the percentage shows that out of 22 students, 15 students indicate a poor category of speaking ability, and 7 other students showed good category. The results of the speaking test are students who get the enough value category enough were 5 students and 2 students who get the highest score.

Whereas in the last cycle, the second meeting, based on the observations result, here were 13 students showing the average category of speaking abilities, and 7 students attend an excellence category, and 2 more students got low category. Then in the last cycle, the results show that students 'abilities are quite high, reaching $50 \%$ of students' average grades categorized as good, $40 \%$ of students entered the excellent category, and only $10 \%$. In this cycle students look more active than in previous cycles, so that the results are as expected. Almost all criteria speaking assessment can be demonstrated and carried out properly by students. The sentences uttered are also quite directed according to the topic learned. 
Overall, the speaking test results showed an increase, though not too flashy. Most students have been able to get better results, so that in the second cycle it is considered sufficient and then the research was stopped. From the findings of several data sources used, as a whole show an increase in the results of the achievement and the affective performance of students. This gives an overview of the positive impact on the application of the scaffolding method used when teaching speaking to the students, in efforts to improve English speaking skills speaking class of batch 2017.

In speaking learning, students are required to have speaking skills the good one. Therefore, the learning process of speaking is expected in a dialogical, interactive, interesting and fun atmosphere, so students more motivated to follow the learning process. Furthermore, skills speaking needs to be trained intensively in order to develop and be fluent maximum for students to control. ${ }^{18,19}$ Mastery of speaking skills can be more fast through practice, therefore when speaking, teacher is better giving students plenty of opportunities to practice and practice directly with the teacher or friend. ${ }^{20,21}$ One effort that can be done by the teacher that is through an intensive learning design improve these skills, namely using scaffolding method. ${ }^{22}$

Through this strategy students are facilitated by teachers with a variety of techniques and activities that are able to provide many opportunities for students to practice speaking contextually, making it more fun and easier learned. ${ }^{23}$ As said that teachers need methods, that work in their particular situation with specific objectives that meaningful for the kind of students they have in their classes on the other hand teachers need the stimulation of a new method or approach from time to time to encourage them in participating in various class activities. ${ }^{24,25}$ It is also added that scaffolding is a process that enables a child or novice to solve a problem, carry out a task or achieve a goal which would be beyond his unassisted efforts. ${ }^{26}$ Scaffolding strategy, students have opportunity to work alone to solve a problem through assignments given by the teacher to achieve learning goals.

\section{Conclusion}

The conclusions from the results of this study are as follows: First, implementation scaffolding method improves the student learning achievement in speaking; second, the application of the scaffolding method can improve; Third student learning motivation, applying the scaffolding method improves students' positive responses to learning activities; Fourth, the application of the scaffolding method improve achievement of student learning outcomes if consistently use this method at each learning activities; Fifth, the application of the scaffolding method improves the quality of students' ideas and ideas so that they are really true produce a good conversation; and, sixth, applying the scaffolding method provides effective means for students on improving English speaking achievement.

\section{References}

[1] Zarandy, S.Z.A and Rahbar, B. Enhancing Speaking Ability through Intervening Scaffolding Strategies, Theory and Practice in Language Studies, 6 (11), 2016.

[2] Richards, J. C. Teaching listening and speaking: From theory to practice. New York, NY: Cambridge University Press. 2008.

[3] Mathew, R. Collaborative Learning-An Effective Method for Teaching Native Arabic Speakers. Journal of Foreign Language Teaching and Applied Linguistics, 2 (2), 2015. 
[4] Saye, J., \& Brush, T. Scaffolding critical reasoning about history and social issues in multimediasupported learning environments. Educational Technology Research \& Development, 50 (3), 2002. 77-96.

[5] Simons, K., \& Klein, J. The impact of scaffolding and student achievement levels in a problembased learning environment. Instructional Science, 35, 2007. 41-72.

[6] Mehrani, M. B., \& Modarresi, G. The Nature of Interactive and Intervening Strategies in Scaffolding EFL Reading Skill. The Iranian EFL Journal, 7 (1), 2011. 116-126.

[7] Poorahmadi, M. The Effect of Employing Scaffolding Strategies and Classroom Tasks in Teaching Reading Comprehension. Journal of Teaching English as a Foreign Language and Literature, 1 (3), 2009. 87-106.

[8] D' Alession, Diane and Margaret Riley. Scaffolding Writing Skill for ESL Students in an Education Class at a Community College. The Wac Journal. 13, 2002.

[9] Schewieter, John W. Developing Second Language Writing through Scaffolding in the ZPD. A Magazine Project for an Authentic Audience. Journal of College Teaching and Learning. 7 (10), 2010.

[10] Yelland, N., \& Masters, J. (2007). Rethinking scaffolding in the information age. Computers and Education, 48, 362-382.

[11] Santoso, A. (2008). The art of scaffolding an EFL writing class in a hybrid environment: A practical experience. International Journal of the Computer, the Internet and Management, 16 (3), 8.1-8.12.

[12] Gibbons, P. Scaffolding language, scaffolding learning: Teaching second language learners in the mainstream classroom. 2002.

[13] Kemmis, S., McTaggart, R., \& Nixon, R. The action research planner: Doing critical participatory action research. Springer Science \& Business Media, 2013.

[14] Robert P. Pelton. Action Research for Teacher Candidates_ Using Classroom Data to Enhance Instruction. R \& L Education, 2010.

[15] Cohen, Louis., Lawrence Manion, \& Keith Morrison. (2007). Research Methods in Education, 6th Edition. New York: Taylor and Francis e-Library.

[16] Ernest, T.S, Christensen, M. \& Baldwin, S. Integrating Teaching, Learning, and Action Research_ Enhancing Instruction in the K-12 Classroom, 2009.

[17] Lisa M. B \& Jill M. A. Student Voice, Teacher Action Research and Classroom Improvement. Sense Publishers, 2014.

[18] Tavakoli, M. \& Rezazadeh, M. Individual and Collaborative Planning Conditions: Effects on Fluency, Complexity and Accuracy in L2 Argumentative Writing. The Journal of Teaching Language Skills (JTLS), 5(4), 2014. 85-110.

[19] Dirk Siepmann, et al. Writing in English: A Guide for Advanced Learners. Germany: Narr Francke Attempto Verlag GmbH \& Co. KG 2008.

[20] Alshumaimeri, Y. A., \& Almasri, M. M. The effects of using WebQuests on reading comprehension performance of Saudi EFL students. TOJET: The Turkish Online Journal of Educational Technology, 11 (4), 2012.

[21] Slavin, R. E. Co-operative learning: what makes group-work work. The nature of learning: Using research to inspire practice, 2010. 161-178.

[22] Naibaho, L. Phonological Acquisition of A Child Suffering from Language Delay. IjlecrInternational Journal of Language Education and Culture Review, 2 (1), 2016. 33-42.

[23] Tyas, E. H., Sunarto, S., \& Naibaho, L. Evaluasi Implementasi Pembelajaran Students Centered Learning oleh Mahasiswa PPL FKIP-UKI Di Sekolah Mitra-PSKD. Jurnal Selaras: Kajian Bimbingan dan Konseling serta Psikologi Pendidikan, 1(1), 2018. 69-80.

[24] Wood, David, Jerome S. Bruner, and Gail Ross. The role of tutoring in problem solving. Journal of Child Psychology and Psychiatry. 17:, 2006. 89-100.

[25] Walton, M., \& Archer, A. (2004). The web and information literacy: Scaffolding the use of web sources in a project- based curriculum. British Journal of Educational Technology, 35(2), 173-186. 
[26] Yuanhua, C and Guocai, C. The Application of Scaffolding Theory Into Oral English Teaching in Middle School. CSCanada Journal on Studies in Literature and Language, 12 (4), 2016, 63-66

*Corresponding author.

E-mail address: lamhot.naibaho@ uki.ac.id 